Provided for non-commercial research and education use. Not for reproduction, distribution or commercial use.

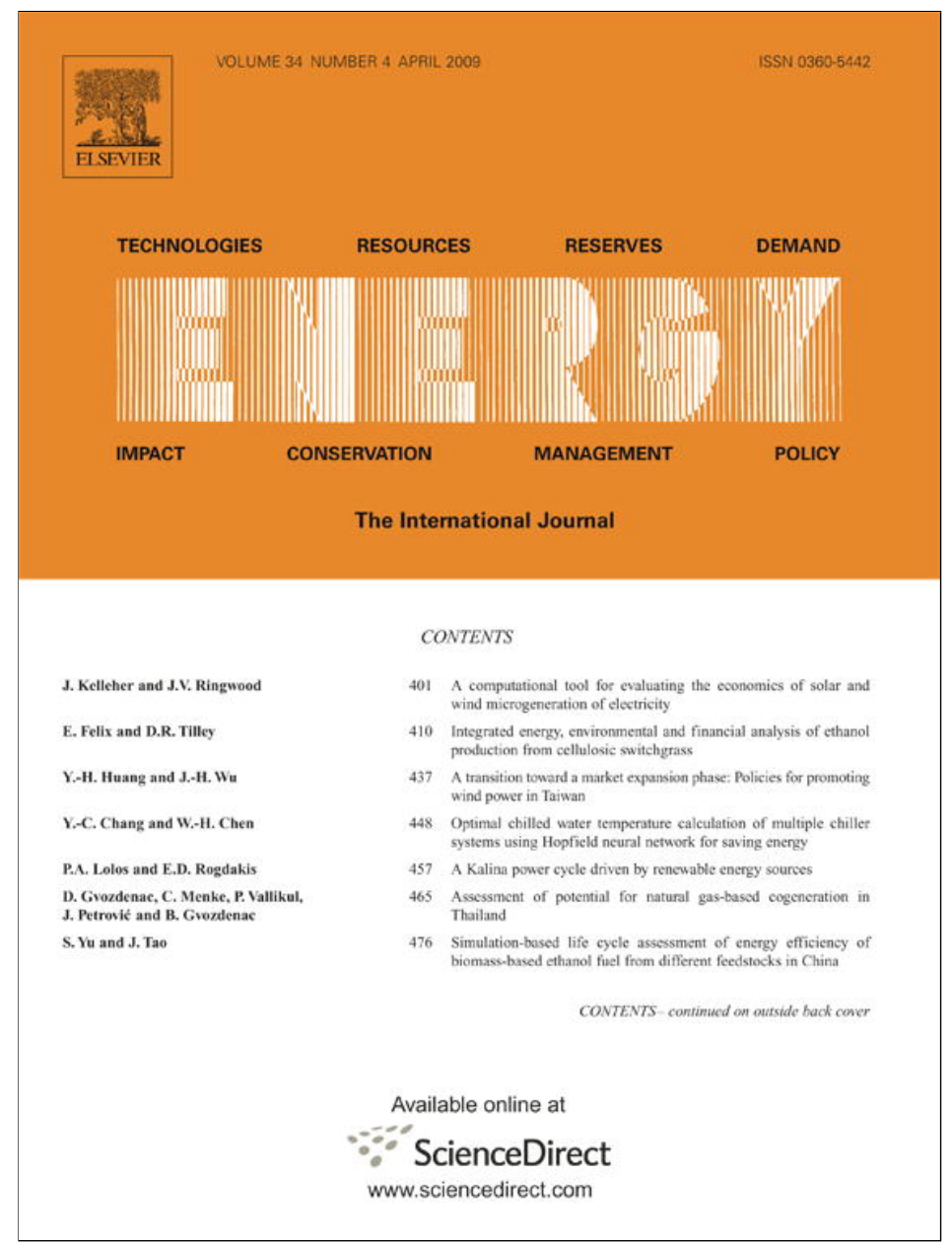

This article appeared in a journal published by Elsevier. The attached copy is furnished to the author for internal non-commercial research and education use, including for instruction at the authors institution and sharing with colleagues.

Other uses, including reproduction and distribution, or selling or licensing copies, or posting to personal, institutional or third party websites are prohibited.

In most cases authors are permitted to post their version of the article (e.g. in Word or Tex form) to their personal website or institutional repository. Authors requiring further information regarding Elsevier's archiving and manuscript policies are encouraged to visit:

http://www.elsevier.com/copyright 


\title{
A computational tool for evaluating the economics of solar and wind microgeneration of electricity
}

\author{
J. Kelleher, J.V. Ringwood* \\ Department of Electronic Engineering, National University of Ireland (NUI), Maynooth, Maynooth, Co. Kildare, Ireland
}

\section{A R T I C L E I N F O}

\section{Article history:}

Received 18 August 2008

JEL Classification:

C65

Keywords:

Microgeneration

Wind power

Solar power

Payback period

Economics

\begin{abstract}
A B S T R A C T
This paper presents a method, implemented as a freely available computer programme, which is used to estimate the economics of renewable microgeneration of electricity from wind and solar energy sources. A variety of commercial small wind turbines and photovoltaic (PV) panels are considered and combined with raw energy data gathered from a variety of locations. Both residential and holiday home user profiles are available and options are selectable concerning feed-in tariffs (if available), government incentive schemes and the cost of capital borrowing. The configuration of the generation setup, which can consist of wind, PV and combination of wind/PV, is fully selectable by the user, with a range of appropriate default data provided. A numerical example, based on Irish data, is presented, which suggests that payback periods for solar and wind microgeneration systems can vary greatly (2.5-500 years), depending on the location, installation and economic variables.
\end{abstract}

(c) 2009 Elsevier Ltd. All rights reserved.

\section{Introduction}

Recent years have seen significant growth in the deployment of electricity generation schemes based on renewable resources. In addition, direct generation from wind turbines and photovoltaic (PV) panels has provided an option at the domestic, or microgeneration, level. However, it still remains unclear as to the relative economics of microgeneration, for specific locations.

For communities with no grid connection, particularly in the developing world $[1,2]$ it may be the only means of achieving electric lighting. However, in a grid-connected developed world, complete with the moral pressure of reducing greenhouse gas emissions, the economics are not as clear-cut. There is a complex interplay of technical, economic and climatic factors, which must be evaluated on a case-by-case basis and with the rapid rate of current technical developments, as well as significant changes in government policies, the situation is a dynamically changing one. Zamora et al. [3] examine the range of technologies currently available for microgeneration.

A number of studies have examined the economics of microgeneration in various locations, such as those by Upson [4] and Dalton et al. [5]. In addition, social and regulatory issues have been explored in $[6,7]$. The economy of microgeneration, in the context of overall supply of electricity to a grid system, has also been considered in [8], taking in to account the effectiveness of a

\footnotetext{
* Corresponding author. Tel.: +3531708 4766; fax: +35317086027.

E-mail address: john.ringwood@eeng.nuim.ie (J.V. Ringwood).
}

range of incentives. Ultimately, however, each household must make a decision in their own individual context embracing the local climatic/weather conditions, financial incentives available for renewables in their local jurisdiction and turbine/PV installations available to them. In addition, they must factor in what overhead they might wish to incur for renewable generation.

While it is difficult to cost the 'green' overhead, it is eminently possible to make a reasonably accurate calculation of the costs associated with the installation of wind turbines or PV cells, offset by any renewable incentives, for the climatic conditions prevalent in a given location. This paper presents a computer application which purports to do just that and can be easily used by a nontechnical user, while providing a number of default parameters and datasets in the case of unknowns. Clearly, however, the accuracy of the power production and cost calculations from the application will depend on the accuracy of the input data, for a particular location.

The computer application described in this paper allows the specification of a range of wind turbines and PV cells and any combination of these can be entered. Details local to the dwelling must also be entered, such as electricity consumption profile, roof orientation, landscape category and economic factors, such as the capital cost of devices, availability of grants or feed-in tariffs and loan annual percentage rate (APR). Battery storage can also be factored in, if available.

While the most of the technical relationships underpinning the application are available in the published literature, the main contribution of the paper is to assemble this knowledge and present it in a convenient and useable form. This is important 
where choices in relation to renewable microgeneration must be made in the face of a dynamic environment where alternative fuel costs, price of electricity and renewable energy conversion technology are rapidly changing.

The remainder of the paper is laid out as follows. Section 2 deals with specification of the load consumption profile, while Sections 3 and 4 articulate the technical issues to do with smallscale wind turbines and PV cells, respectively. Section 5 concerns the economic considerations associated with a renewable microgeneration system, and Section 6 discusses the computer implementation of the calculations, including the user interface. An application example, utilising Irish location data, is presented in Section 7 and conclusions are drawn in Section 8.

\section{Domestic electricity consumption profiles}

A data record representing a nominal consumption profile for the dwelling of interest needs to be provided. Given seasonal variations in electricity consumption (and seasonal variations in renewable energy resources), it is necessary to specify the domestic load over a complete year, in order that a result is received which has some independence from seasonal factors. In order to correlate load and supply with a reasonable degree of accuracy at the daily level, loads (and supply from microgeneration) are specified as hourly values, in $\mathrm{kWh}$.

Exact specification of such a load curve would require recording of local domestic load to take place over a complete year before an analysis could be performed, but an alternative is to use a mean domestic load profile, determined from the domestic supply curve of a utility. The mean load curve is simply evaluated as the total domestic hourly load points (in $\mathrm{kWh}$ ) divided by the number of households. Example load curves (for an Irish household) are shown in Fig. 1 and form the basis of the default data.

Since electrical energy consumption is, on average, significantly higher in winter than summer (due to additional lighting and heating requirements), this needs to be represented in the annualised load curve. For the default data, the complete load curve is obtained by taking 4 representative days equally spaced across the year and interpolating (using cubic splines) between them to give a load value for each hour of the year. Such an averaging procedure gives no recognition to the special events of holiday periods (summer, Christmas), weekend days or bank holidays but, in the absence of a specific dwelling load curve, gives reasonable default data to allow variations in other parameters to be examined.

In order to provide a default profile for a holiday home scenario, a typical occupancy pattern (for the Northern Hemisphere) is identified in Table 1. It is assumed that load is identical to residential dwelling for occupied dates and zero otherwise.

\section{Microgeneration from wind}

\subsection{Resource quantification and representation}

The energy resource data required for the wind turbine part of the application is provided as average hourly wind speed measurements, in $\mathrm{m} / \mathrm{s}$, over a complete year. Since wind speed varies significantly with height of measurement, we can use the formula in Eq. (1) to calculate wind velocity, $v$ at any height, $h$, given a measurement $v_{0}$ at height $h_{0}$ [9], as

$v=\left(h / h_{0}\right)^{\alpha} v_{0}$

where $\alpha$ is a roughness coefficient and can be determined from the broad specifications in Table 2 . In addition, compensation needs to be applied to allow for a wind speed reduction due to turbulence

Table 1

Typical occupancy for holiday home usage.

\begin{tabular}{ll}
\hline Month & Typical occupancy dates \\
\hline January & $1-3$ \\
February & $15-17,27-31$ \\
March & \\
April & $3-4,10-11,17-18,24-25,31$ \\
May & $1-30$ \\
June & $1-31$ \\
July & $1-31$ \\
August & $6-7,13-14,20-21,27-28$ \\
September & $25-27$ \\
October & $30-31$ \\
November & \\
December & \\
\hline
\end{tabular}

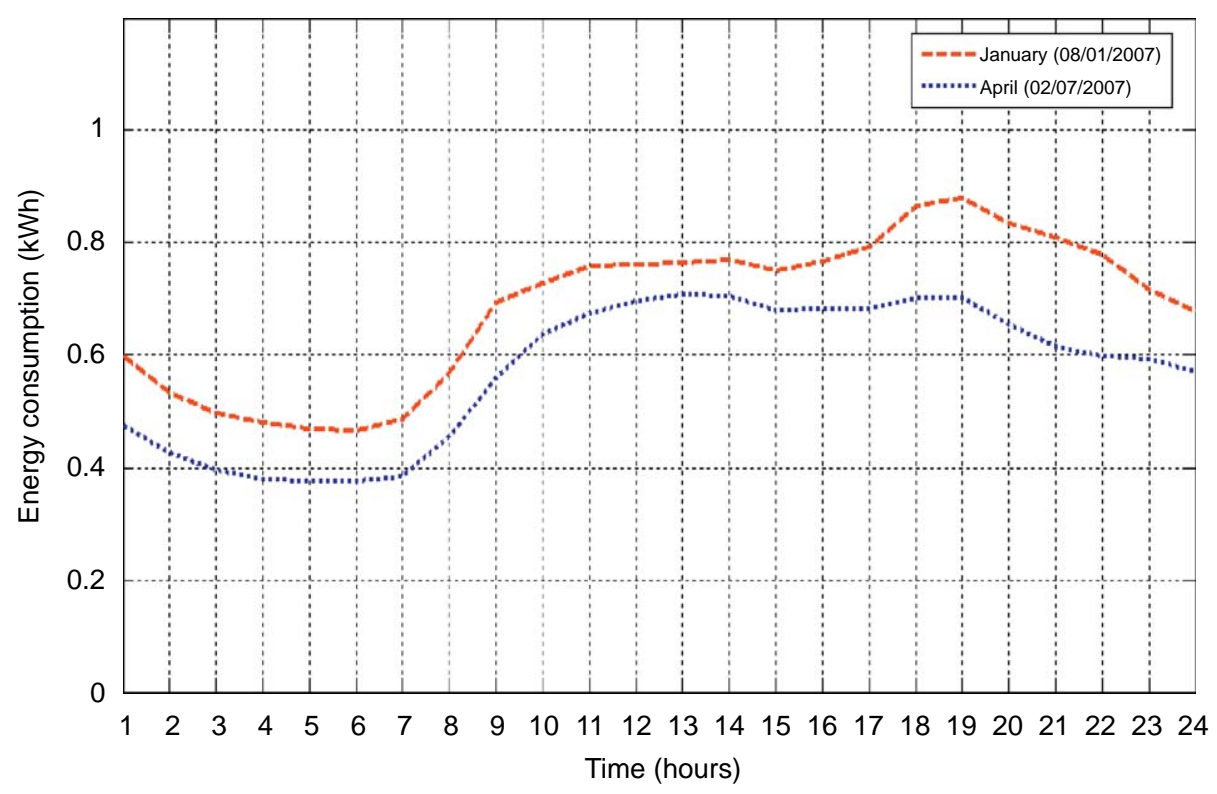

Fig. 1. Average load curves for an Irish dwelling. 
[10], caused by ground obstructions, via Eq. (2) and Table 3:

$v_{t}=v(1-0.01 \beta)$

Wind resource data from three locations in Ireland (Dublin Airport, Kilkenny and Belmullet) is currently selectable as default data in the application programme.

\subsection{Wind turbine specification}

At the time of writing, a significant variety of small wind turbines were available and the variety is likely to increase significantly in the future. Turbines are characterised by their power curves, which define the power output, in Watts, for a given wind speed, in $\mathrm{m} / \mathrm{s}$, and takes into account all effects including blade aerodynamics and auto-furling/stall effects, electrical generator, any gearing and the power electronics associated with the turbine itself. Fig. 2 shows a typical set of power curves for three popular turbines, by way of example. The power curves are parameterised by

- the cut-in speed (typically approx. $5 \mathrm{~m} / \mathrm{s}$ for the turbines in Fig. 2),

- the rated power, which is the power value corresponding to the 'flat' part of the curve, e.g. approx. $2750 \mathrm{~W}$ for the Proven device in Fig. 2, and

\section{Table 2}

Roughness coefficients for landscape type.

\begin{tabular}{ll}
\hline Site type & Roughness coefficient, $\alpha$ \\
\hline Flat grassy plains & 0.01 \\
Rural with obstacles & 0.3 \\
Cities and forests & 0.7 \\
\hline
\end{tabular}

Table 3

Wind turbulence coefficient for a variety of site types.

\begin{tabular}{lc}
\hline Site type & Percent turbulence coefficient, $\beta$ \\
\hline Large flat plain & 0 \\
Open rural area & 10 \\
Urban area & 30 \\
\hline
\end{tabular}

- the cut-out speed, at which the turbine is shut down to keep loads from reaching damaging levels.

The rotational speed of small turbines is typically regulated by blades which stall or auto-furl in higher wind conditions, while larger devices have variable pitch control, which regulates turbine rotational speed. One difficulty, for small turbines, is obtaining power curve descriptions which extend upwards of $15-20 \mathrm{~m} / \mathrm{s}$ wind velocity. To this end, we have made the following assumptions:

A1. For auto-furl systems, the power curves tail off in a manner similar to the B\&Q $1.2 \mathrm{~kW}$ device, beyond their rated furling speeds, and

A2. For variable pitch devices, rated power is produced for all wind speeds in excess of the initial wind speed at which rated power is produced.

Data for the following wind turbines is included in the application: Stealthgen $400 \mathrm{~W}$, Proven $600 \mathrm{~W}$, B\&Q $1.2 \mathrm{~kW}$, Swift $1.5 \mathrm{~kW}$ and Proven $2.5 \mathrm{~kW}$, covering a range of suppliers and rated power specifications.

The losses incurred in grid connection are user specified, with a nominal value of $10 \%$. Finally, the number of turbines which can be accommodated on a particular site can be estimated by allowing a spacing of 10 rotor diameters in the turbine axial direction and 3 rotor diameters in the cross-axial direction, where both dimensions are available as inputs to the application.

\section{Microgeneration from PV}

\subsection{Resource quantification and representation}

Hourly solar radiation data is used as the raw solar energy input to the application. Global irradiance, measured in $\mathrm{W} / \mathrm{m}^{2}$, represents a combination of direct and diffuse radiation incident at a point and is used in the current calculations. Default data for the application provides global irradiance data for the same three locations as reported in Section 3.1.

\subsection{Solar cell specification}

Solar cells normally produce a nominal output voltage of $12 \mathrm{~V}$, with the output current depending on the incident solar radiation,

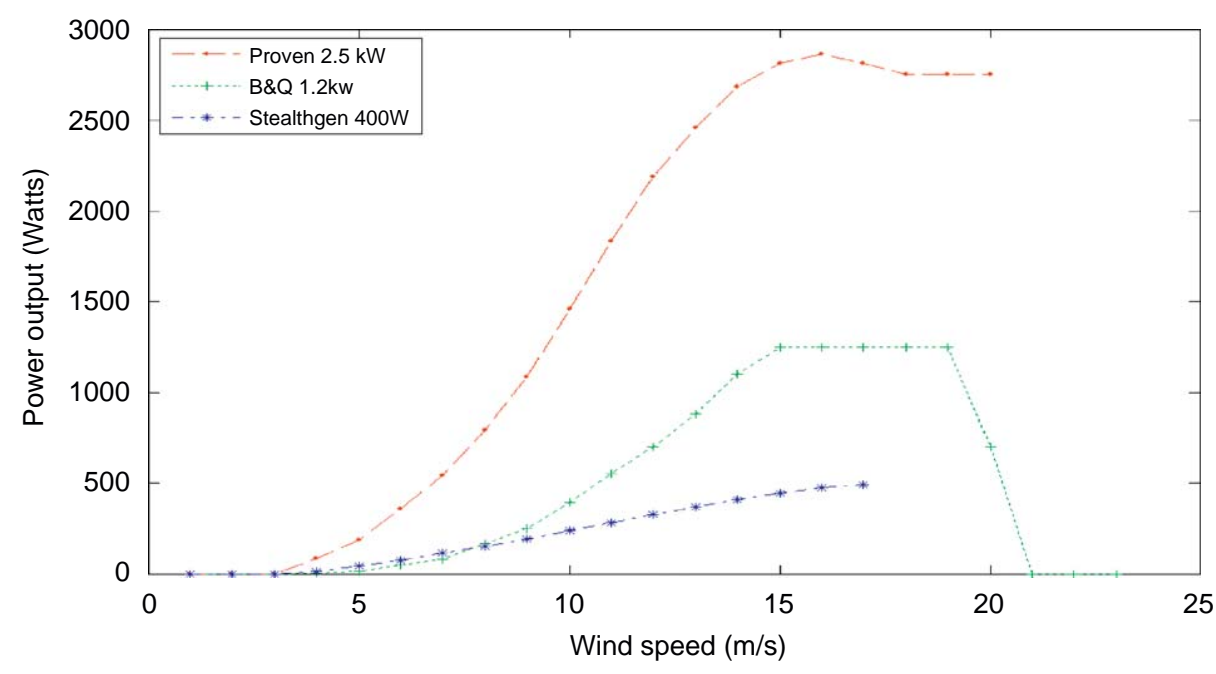

Fig. 2. Example turbine power curves. 


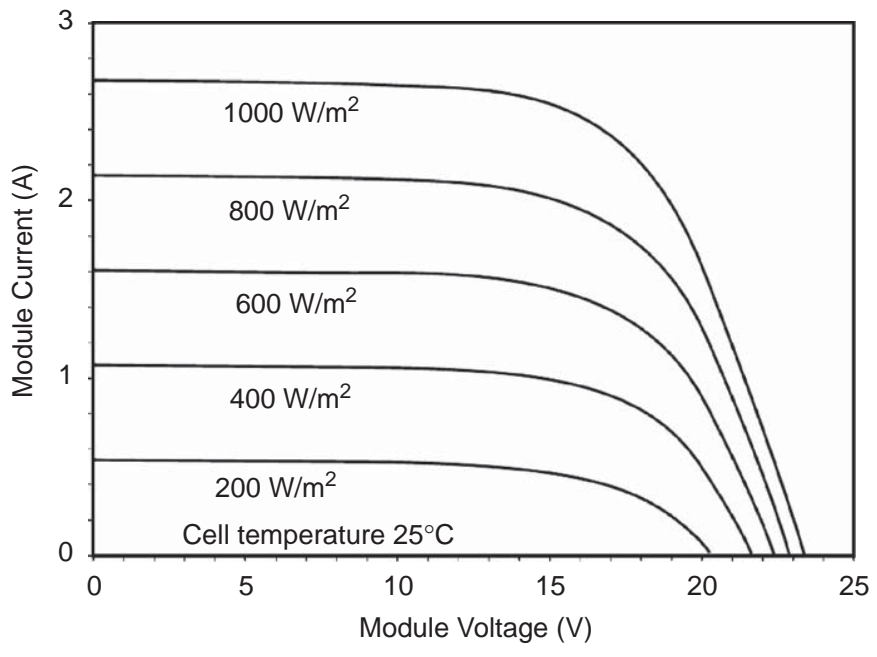

Fig. 3. Power curves for Kyocera KC125G (125 W) module.

i.e. they are current sources. The power curve for a solar cell plots current (in A) against voltage (in Volts) with each trace parameterised for a specific incident radiation level. By way of example, Fig. 3 shows the power curves for the Kyocera KC125G $(125 \mathrm{~W})$ module at various levels of solar intensity. Data for the Shell ST40 (40W), Photowatt PW750 (85 W), Kyocera KC125G (125 W), Sharp NE-165U1 (165 W) and Sharp NT-180U1 (180 W) are included in the application, while user-defined power curves can also be included.

\subsection{Site-specific conditions}

While an important site factor in available power relates to the intensity of the solar radiation and the degree to which this is achieved over time (relating to cloud cover), two further sitespecific factors also determine the actual electrical energy output. These are the orientation of the PV surface relative to the sun and the temperature variations at the site.

With respect to orientation, the output current is determined [11] by

$I=I_{0} \cos \theta$

where $I_{0}$ is the reference current achieved with the sun rays normal to the PV surface, $\theta$ is the angle of incidence between the solar beam and the PV surface and $I$ is the cell output current. $\theta$ is calculated using [12]

$\cos \theta=(A-B) \sin \delta+[C \sin \omega+(D+E) \cos \omega] \cos \delta$

with

$$
\begin{aligned}
& A=\sin \phi \cos \beta \\
& B=\cos \phi \sin \beta \cos \gamma \\
& C=\sin \beta \sin \gamma \\
& D=\cos \phi \cos \beta \\
& E=\sin \phi \sin \beta \cos \gamma
\end{aligned}
$$

where $\phi$ is the collector latitude, $\beta$ is the collector slope (relative to horizontal), $\gamma$ is the collector azimuth (relative to due south in counter-clockwise direction), $\omega$ is the solar hour angle and $\delta$ is the solar declination.

The solar hour angle is the angle through which the earth has rotated since solar noon (highest position of sun) and the solar declination is the angle between the Sun's direction and the equatorial plane, calculated using

$\delta=\delta_{0} \sin \left[\frac{360(284+n)}{365}\right]$

where $n$ is the day of the year (with $n=1$ on the first of January) and $\delta_{0}=23.45$. Note that Eq. (4) must be applied with care, for example in the case where $\theta$ is greater than $90^{\circ}$ and $\cos \theta$ is therefore negative. In such cases, the PV power output is zero. In addition, beyond $\theta=50^{\circ}$, the power output of PV modules begins to deviate from that predicted by Eq. (3). To account for this, the Kelly cosine table [11] can be used to estimate the effective cosine of the angle between the solar beam and the PV module.

Finally, the dependence of the power output on the module temperature is considered [11] as

$p=p_{0}[1-0.005 \Delta T]$

where $p$ is the power output of the module at $T_{\text {module, }}, p_{0}$ is the power output of the module at $25^{\circ} \mathrm{C}$ and $\Delta T$ is the absolute difference between $T_{\text {module }}$ and $25^{\circ} \mathrm{C}$ (the standard testing temperature for PV modules). $T_{\text {module }}$ can be calculated [13] as

$T_{\text {module }}=0.943 T_{\text {ambient }}+0.028 I_{s}-1.528 v_{w}+4.3$

where $T_{\text {module }}$ and $T_{\text {ambient }}$ are measured in degrees Celsius, $I_{s}$ is the solar irradiance in $\mathrm{W} / \mathrm{m}^{2}$ and $v_{w}$ is the wind velocity in $\mathrm{m} / \mathrm{s}$.

\section{Economic considerations}

In order to perform a comparative cost/benefit analysis, it is assumed that the capital cost of the renewable energy system (including asset cost and cost of installation) will be funded from a loan, amortised over the lifetime of the asset, using the standard formula given by

$M=P\left[i(1+i)^{n}\right] /\left[(1+i)^{n}-1\right]$

where $M$ is the monthly repayment on the loan, $i$ is the APR/12 (APR $=$ annual percentage rate), $P$ is the principle, i.e. the total cost of the microgeneration installation and $n$ is the number of months.

A possible feed-in tariff is included in the application, since a number of jurisdictions (excluding Ireland) facilitate feed-in for small installations. In addition, the application provides the possibility for storage of excess energy using batteries, for example using a $24 \mathrm{~V} 230 \mathrm{Ah}$ low-maintenance battery, quoted in Proven Energy's price list at 489 Euro. Such a battery can store $5.52 \mathrm{kWh}$ of energy, corresponding to a capital cost of 88.86 Euro/ $\mathrm{kWh}$ of storage. The effectiveness of battery storage for microgeneration applications is considered further in [14].

\section{The computer program}

The application was developed in Matlab ${ }^{\circledR}$ (Version 7) and features a graphical user interface (GUI) for data entry and presentation. Fig. 4, by way of example, shows a flowchart for the PV section of the application. Full flowchart and algorithm details can be found in [15]. The application provides for the set of user inputs and produces possible outputs, as shown in Table 4. The graphical user interface is shown in Fig. 5.

\section{Irish application example}

For illustration, some sample results, using Irish weather data, are shown in this section. Complete weather data was available for three locations: Belmullet (West Coast), Dublin Airport 


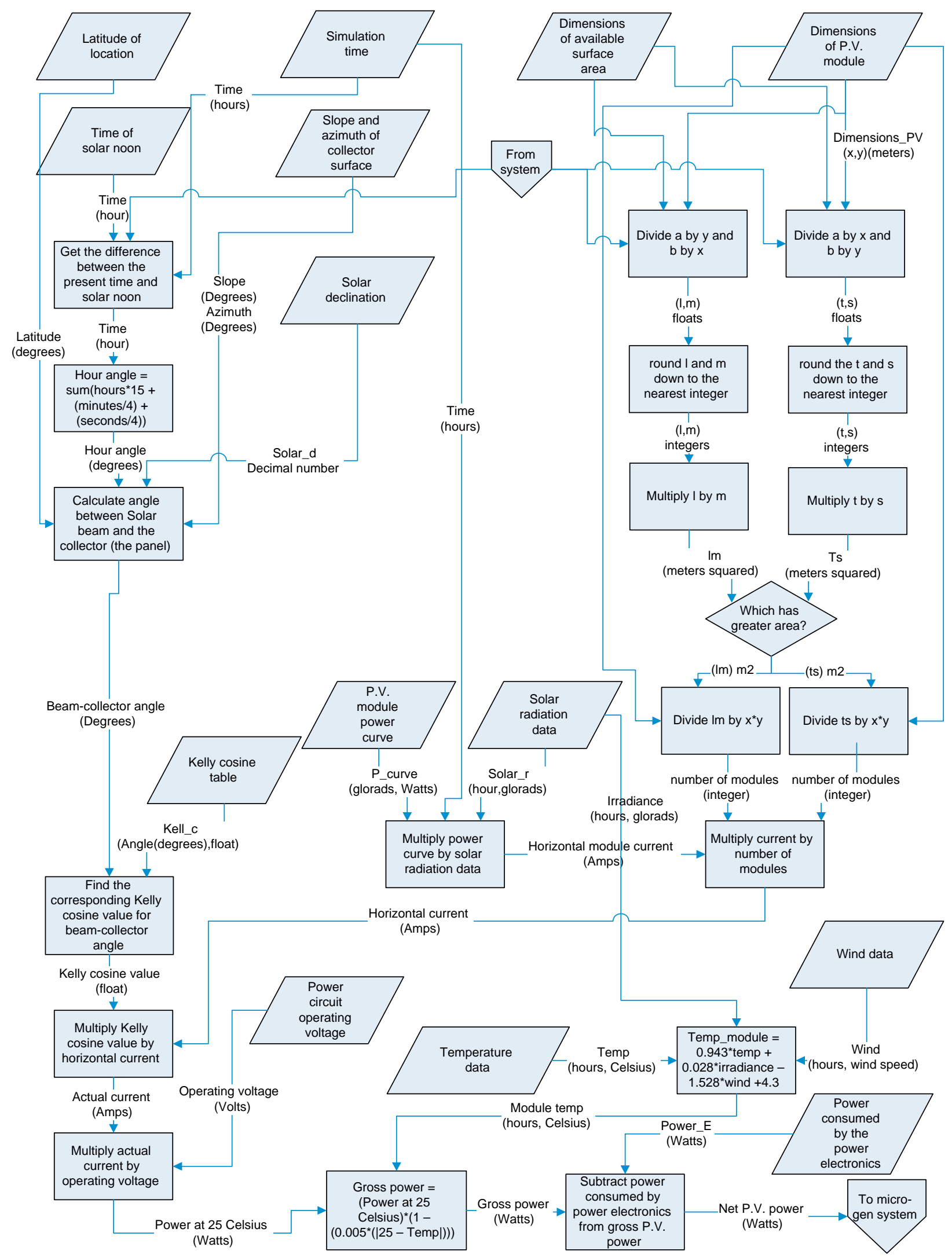

Fig. 4. Flowchart for PV section of application.

(East Coast) and Kilkenny (South East), with average wind speeds of $11.97,10.95$ and $7.15 \mathrm{~m} / \mathrm{s}$ at a $10 \mathrm{~m}$ height, respectively. There is little significant difference in solar insolation or cloud cover between the three locations. Data for the wind turbines and PV panels is given in Table 5. Note that where an installation cost has not been indicated from the manufacturer, an amount of $€ 1000$ is 
Table 4

User inputs and selectable outputs for the application.

\begin{tabular}{|c|c|}
\hline \multicolumn{2}{|c|}{ Inputs } \\
\hline 1 & Wind speed data \\
\hline 2 & Wind turbine site description \\
\hline 3 & Height of wind turbine \\
\hline 4 & Wind turbine specification \\
\hline 5 & Axial space \\
\hline 6 & Cross-axis space \\
\hline 7 & Minimum number of turbines \\
\hline 8 & Solar radiation data \\
\hline 9 & PV module specification \\
\hline 10 & Time of solar noon data \\
\hline 11 & Ambient temperature data \\
\hline 12 & PV module azimuth \\
\hline 13 & PV module slope \\
\hline 14 & Roof length \\
\hline 15 & Roof width \\
\hline 16 & PV module dimensions \\
\hline 17 & Loan period \\
\hline 18 & Loan APR \\
\hline 19 & $\mathrm{~kW} h$ retail cost \\
\hline 20 & Electrical load curve to be used \\
\hline 21 & Capital cost of microgeneration system \\
\hline 22 & Percent energy storage efficiency \\
\hline 23 & Energy storage capacity \\
\hline 24 & Percent inverter efficiency \\
\hline 25 & Grant percentage \\
\hline 26 & Energy feed-in tariff \\
\hline \multicolumn{2}{|c|}{ Outputs } \\
\hline 1 & Payback period \\
\hline 2 & Monthly repayment \\
\hline 3 & Discounted monthly repayment \\
\hline 4 & Total system energy output \\
\hline 5 & Wind turbine energy output \\
\hline 6 & Solar module energy output \\
\hline 7 & Energy held in storage \\
\hline 8 & Solar radiation data \\
\hline 9 & Wind speed data \\
\hline
\end{tabular}

added on. The smaller wind turbines are assumed to be installed on the dwelling, where as the larger turbines, such as the Proven $2.5 \mathrm{~kW}$, are assumed to be installed on a tower with the prices quoted reflecting this. A capital loan with $10 \%$ APR is assumed, unless otherwise stated.

For an average residential dwelling in Belmullet, Table 6 shows the payback period in years for a variety of wind turbines, under a variety of site conditions. A turbine height of $5 \mathrm{~m}$ is assumed, along with $1 \mathrm{~kW}$ of available battery storage. The un-bolded figures correspond to a case where no capital grant or feed-in tariff is available, while the figures in bold assume a 50\% capital grant and a feed-in tariff of $€ 0.13$, equal to the retail price of electricity. A load curve as detailed in Section 2 was utilised.

Clearly, some wind generation cases show a reasonable paypack period, particularly when financial incentives are available. For PV generation, the situation is not so promising, as documented in Table 7, which shows the payback period for a single PV panel. Again, the bold figures show the payback for the case of a $50 \%$ capital grant and a feed-in tariff of $€ 0.13$.

From the lengthy payback periods indicated in Table 7, Ireland has not got sufficient solar intensity (and probably too great an average cloud cover) to make PV generation economic, even with significant financial incentive. In general, it is also found that the situation is considerably worse for holiday home occupancy, since the capital repayment dominates. The application also allows the sensitivity to various individual parameters to be determined, as demonstrated in Figs. 6-9, for which a combined installation of $1 \times$ Proven $2.5 \mathrm{~kW}$ wind turbine, and $2 \times$ Kyocera $125 \mathrm{~W}$ PV panels was employed.

Fig. 6 shows the relative effects of various financial incentives for microgeneration, assuming a loan period of 10 years, \%APR of $10 \%$ and a cost per $\mathrm{kW}$ h of 0.13 cent. While the payback period can be significantly affected by variations in the feed-in tariff, the sensitivity of payback period to capital grant level is small.

Fig. 7 shows the sensitivity of payback period to loan parameters, with the assumption of a feed-in tariff of $0.13 \mathrm{Euro} / \mathrm{kWh}$ and a grant level of $50 \%$. There is significant sensitivity to both \%APR and loan duration, which will impact both the ability of the borrower to make repayments, while also showing the effect of the variation in interest rate in different jurisdictions.

Fig. 8 shows the sensitivity of payback period to the price of electricity (supply), assuming a loan period of 10 years, \%APR of $10 \%$, a feed-in tariff of $0.13 \mathrm{Euro} / \mathrm{kWh}$ and a grant level of $50 \%$. Clearly, one might imagine that the cost of electricity may rise significantly in the relatively near future, which will significantly change the economics of microgeneration, as Fig. 8 shows.

One might also anticipate that improvements in materials will result in increases in PV cell efficiency. To examine the impact of improvements in PV cell efficiency, efficiency values of $10-50 \%$ were used, over-riding the default power curve for the Kyocera $125 \mathrm{~W}$ PV modules. However, Fig. 9 suggests that, for the geographical area under consideration (Belmullet, Ireland), the economy of the installation has little sensitivity to PV cell efficiency. This is, in part at least, likely to be due to the fact that the combined solar/wind installation is not heavily reliant on electricity production from the PV cells. The parameters for this case were a loan period of 10 years, \%APR of $10 \%$, a feed-in tariff of $0.13 \mathrm{Euro} / \mathrm{kWh}$, a grant level of $50 \%$ and a cost per unit of $0.13 \mathrm{Euro} / \mathrm{kWh}$.

Some general comments on these results are appropriate. In general, they represent a small (example) set of possible results, which can be generated from the application and are not designed to provide a definitive picture on the economics of microgeneration in Ireland. One of the difficulties is the rapid rate of change in renewable technology and associated government incentives for their installation, mainly driven by downward pressure on carbon emissions. For example, no feed-in tariff for microgeneration is currently available in Ireland, where microgeneration is defined to be a generator with a max power output of $5.75 \mathrm{~kW}$. However, a feed-in tariff of $€ 0.07 \mathrm{kWh}$ was being mooted at the time of writing. This is one of the motivations behind the development of this application: That it provides a easy-to-use method of examining various microgeneration scenarios in a dynamic way.

\section{Error analysis}

This section attempts to quantify any assumptions made in the calculations, which could be possible error sources and to examine the integrity of the output from the computer programme. In relation to error sources in the calculations we can list the following as potential sources:

\section{Specification of wind turbine output}

- The analytical calculations of Eqs. (1) and (2) involve some approximation in the parameterisation of the relationships describing variation in effective wind velocity with height and surface roughness, but are likely to involve less than $10 \%$ error.

- Some assumptions, detailed in Section 3.2, have been made concerning the complete specification of the wind turbine power curves. While there is likely to be little 

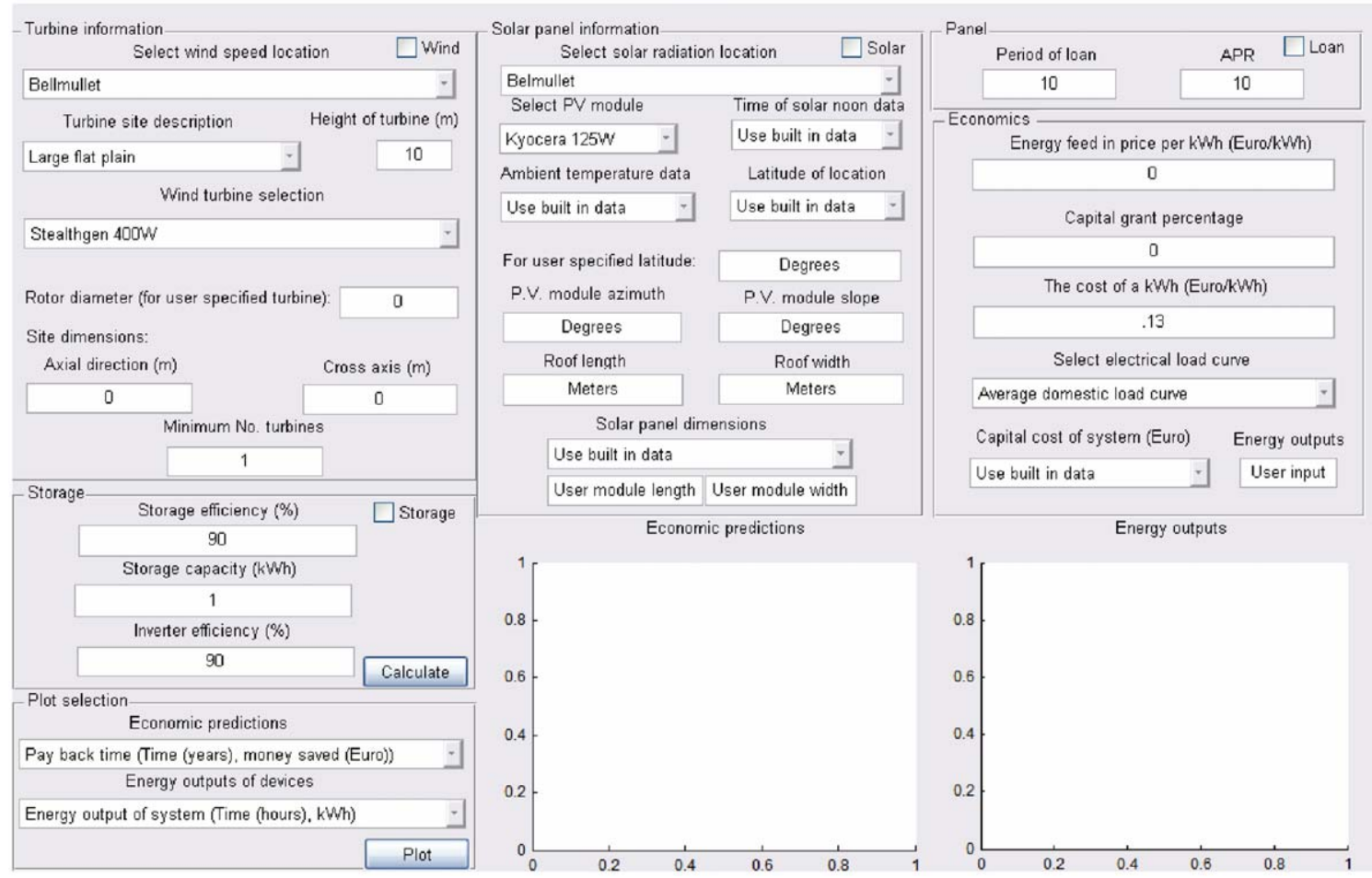

Fig. 5. Graphical user interface to application.

Table 5

Indicative cost of wind turbines and PV modules.

\begin{tabular}{lccc}
\hline Wind turbine & & & PV panels \\
\cline { 3 - 4 } Turbine & Cost (Euro) & Lifetime (years) & Module name \\
\hline Stealthgen $400 \mathrm{~W}$ & 2089 & 10 & Shell ST40 \\
Proven $600 \mathrm{~W}$ & 4497 & 25 & Photowatt PW750 \\
B\&Q 1.2 kW & 2363 & 10 & Kyocera KC125G \\
Swift $1.5 \mathrm{~kW}$ & 5782 & 20 & Sharp NE-165U1 \\
Proven $2.5 \mathrm{~kW}$ & 10,083 & 25 & Sharp NT-180U1 \\
\hline
\end{tabular}

Table 6

Payback period (in years) for micro-wind generation.

\begin{tabular}{|c|c|c|c|c|c|}
\hline & Stealthgen $400 \mathrm{~W}$ & Proven $600 \mathrm{~W}$ & B\&Q $1.2 \mathrm{~kW}$ & Swift $1.5 \mathrm{~kW}$ & Proven $2.5 \mathrm{~kW}$ \\
\hline \multirow[t]{2}{*}{ Large flat } & 15.44 & 14.78 & 7.16 & 10.16 & 5.43 \\
\hline & 7.75 & 7.38 & 3.58 & 5.08 & 2.71 \\
\hline \multirow[t]{2}{*}{ Open rural } & 21.56 & 18.59 & 8.86 & 12.80 & 7.30 \\
\hline & 10.82 & 9.29 & 4.43 & 6.40 & 3.65 \\
\hline \multirow[t]{2}{*}{ Urban } & 57.59 & 41.33 & 28.86 & 33.43 & 17.99 \\
\hline & 28.91 & 20.66 & 14.43 & 16.71 & 8.99 \\
\hline
\end{tabular}

bias in the assumption regarding auto-furling turbines (Assumption A1), the assumption of rated power to cut-out (Assumption A2) may involve a slight overestimation of power output, for pitch-controlled turbines.

2. PV calculations

The calculations of Eqs. (3)-(5) are exact. However, Eqs. (6) and (7) involve some degree of parameterisation error, which is estimated at less than $10 \%$.
3. Economic calculations

The mortgage calculations are exact provided the loan interest is amortised on a monthly basis. Other situations can easily be programmed in the application.

4. User-defined input data

The user is, of course, responsible for the accuracy and integrity of the data input to the application; however, some comment is pertinent regarding the provision of default data. 
Table 7

Payback period (in years) for PV generation.

\begin{tabular}{cllcrc}
\hline Location & Shell & $\begin{array}{l}\text { Photowatt } \\
\text { 40W }\end{array}$ & $\begin{array}{l}\text { Kyocera } \\
125 \mathrm{~W}\end{array}$ & $\begin{array}{c}\text { Sharp } \\
165 \mathrm{~W}\end{array}$ & $\begin{array}{l}\text { Sharp } \\
180 \mathrm{~W}\end{array}$ \\
\hline Kilkenny & 615.82 & 483.68 & 206.18 & 225.53 & 255.58 \\
& $\mathbf{2 3 3 . 5 7}$ & $\mathbf{1 8 7 . 8 6}$ & $\mathbf{8 2 . 9 2}$ & $\mathbf{9 5 . 5 5}$ & $\mathbf{1 1 1 . 2 9}$ \\
& & & & & \\
$\begin{array}{c}\text { Dublin } \\
\text { airport }\end{array}$ & $\mathbf{2 4 3 . 4 5}$ & $\mathbf{1 9 9 . 3 6}$ & $\mathbf{8 6 . 2 3}$ & $\mathbf{9 9 . 4 2}$ & $\mathbf{1 1 5 . 8 8}$ \\
& & & & & \\
Belmullet & 631.17 & 490.05 & $\mathbf{2 1 1 . 6 2}$ & 231.41 & 262.12 \\
& $\mathbf{2 3 9 . 3 9}$ & $\mathbf{1 9 0 . 3 4}$ & $\mathbf{8 5 . 1 1}$ & $\mathbf{9 8 . 0 4}$ & $\mathbf{1 1 4 . 1 3}$ \\
\hline
\end{tabular}

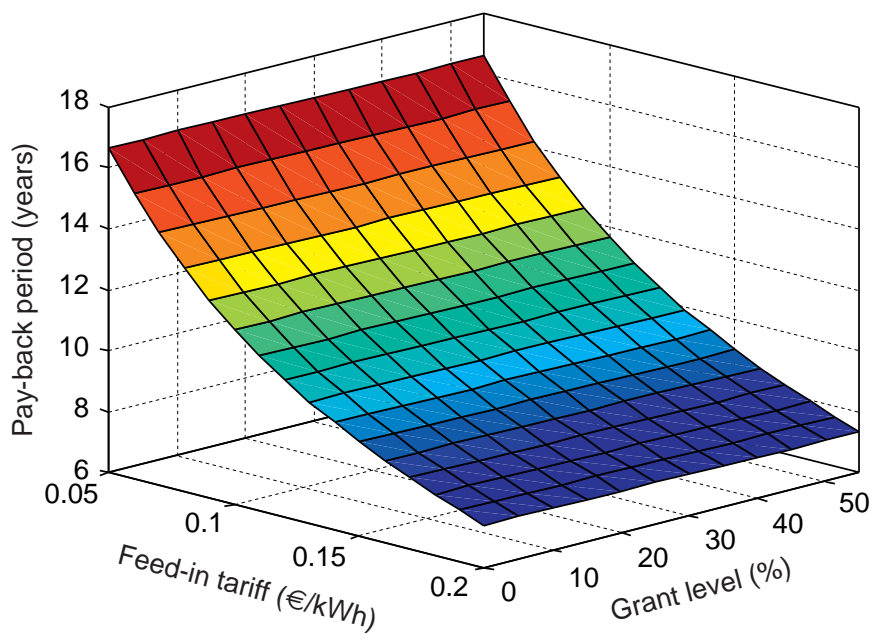

Fig. 6. Sensitivity of payback period to financial incentives.

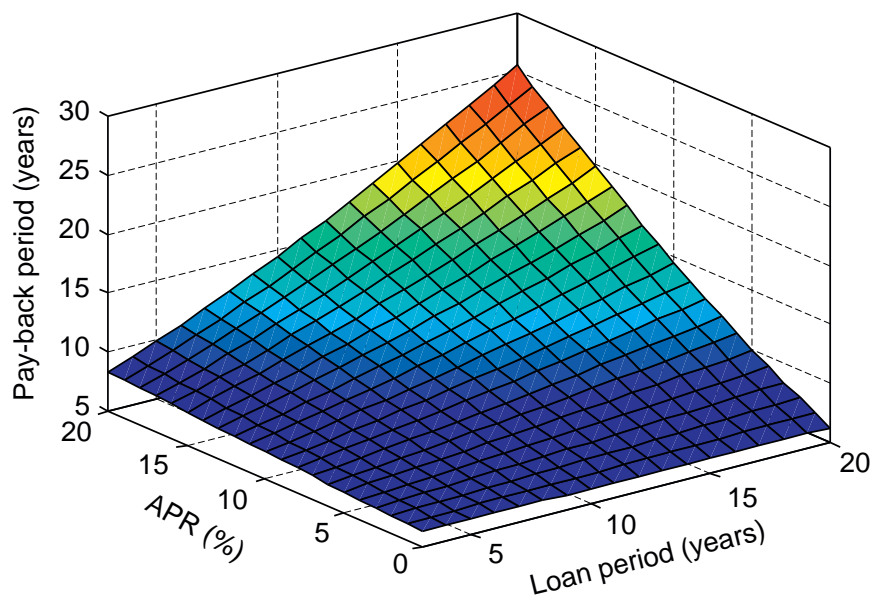

Fig. 7. Sensitivity of payback period to capital loan parameters.

Weather data is supplied and used on an hourly basis, involving a degree of granularity. However, hourly data presents a reasonable compromise between data granularity and ease of handling and is the typical level of discretization used for historical metrological data. Some comment is also pertinent in relation to the sample load data. This data is provided as averaged household data and therefore is likely to be smoother than a single household consumption. Individual domestic loads, containing significant peaks (up to $40 \mathrm{~kW}$ ) and

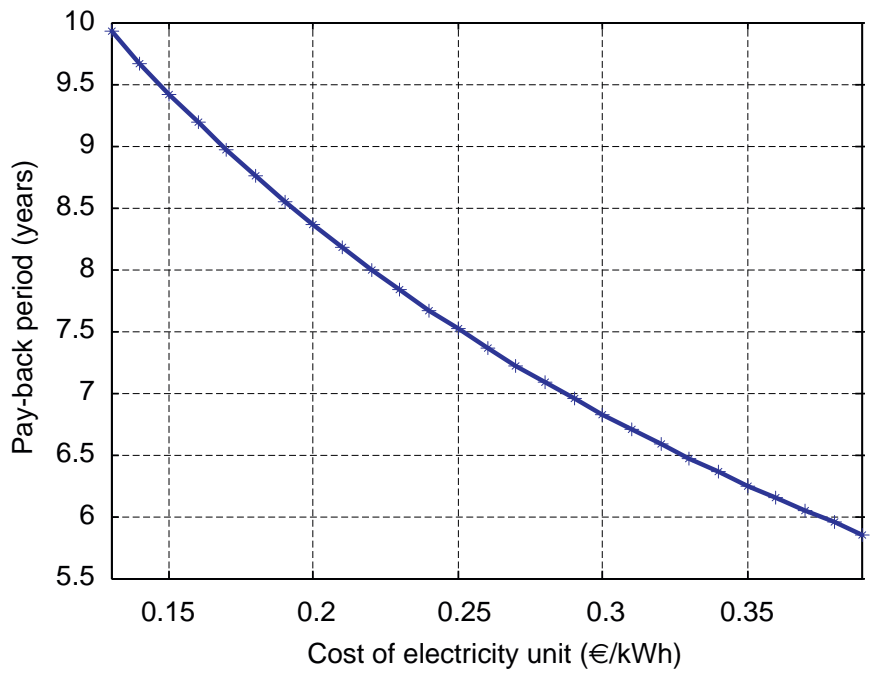

Fig. 8. Sensitivity of payback period to cost of electricity.

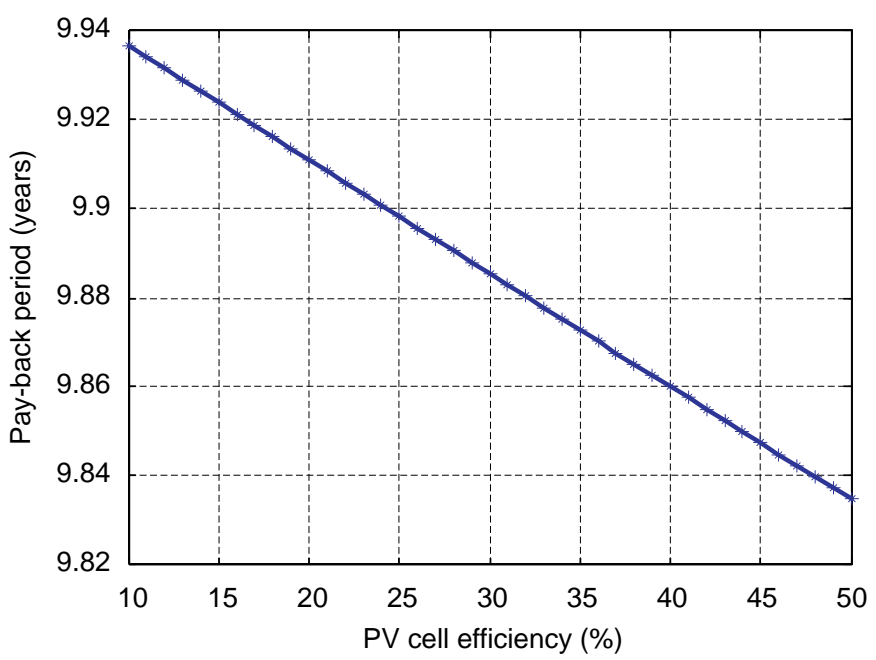

Fig. 9. Sensitivity of payback period to PV cell efficiency.

valleys (with only nominal refrigeration loads) may present significantly more challenge for renewable generation sources, particularly in the absence of electricity storage. Therefore, application users are strongly encouraged, where possible, to enter their own data. The assumptions concerning the default holiday home data are relatively coarse, but users can specify exactly the typical consumption profile for their own situation.

Finally, the application has been exhaustively checked for integrity of output (within the limits of documented approximation) and produces figures broadly in line with other studies.

\section{Conclusions}

A computer application has been presented, which has the capability of examining variations in energy production and 
economics due to variations in climatic conditions, financial incentives, storage capacity and device type associated with a specific micro-renewable installation. This allows a relatively exact analysis to be performed for a specific location, under current technical and cost conditions. In addition, since the microrenewable market is a dynamic one, scenario testing for various projected possibilities is also easily carried out.

Though this paper does not purport to give a definitive answer regarding the economics of renewable microgeneration in Ireland, some broad conclusions regarding the application example can be made. In terms of raw renewable resources, Ireland is better positioned to take advantage of wind rather than solar insolation. However, relatively higher cost (and relatively lower efficiency) of PV cells, compared to wind turbines is a mitigating factor, for the Irish scenario. There appears to be relatively small sensitivity of micro-renewable economics to location in Ireland, which is probably unsurprising, given Ireland's relatively small size and consistent climatic conditions across the country. The economics for a holiday residence appear to be significantly more discouraging than for a permanent dwelling and it can be said that, in general, the broad findings of the application example, in terms of payback periods, are not inconsistent with other reports, e.g. [4]. Sensitivity to both capital grants and feed-in tariff rates is reasonably significant and calculations, such as those available through this application, are useful in the determination of incentives which encourage maximum penetration at minimum cost.

In terms of future evolution in microgeneration technology, likely possibilities include the availability of new types of wind turbines and PV cells, for example organic PV cells [16] and current trends in PV cell manufacturing costs and materials promise electricity generation costs comparable to some fossil fuels [17]. The application can easily incorporate such new data using the present code, by including new device specification files. Other evolutions, such as new storage possibilities, including flow batteries [18] and capacitors [19], and intelligent management of combined solar/PV microgeneration systems [20] would require minor adjustments to the main application code.

We would invite readers would experiment with our application, to determine some measures which may assist them if considering a microgeneration project. The application, developed using Matlab Version 7, Release 14, along with a small user guide, is free to download from: http://www.eeng.nuim.ie/ jringwood/ teaching.htm.

\section{Acknowledgements}

The authors are grateful for the supply of data from Met Eireann, the Irish Meteorological Office and EirGrid, the Irish transmission system operator.

\section{References}

[1] Lysen EH. Photovolts for villages. IEEE Spectrum 1994;31(10):34-9.

[2] Fairley P. Lighting up the Andes [LED lamps]. IEEE Spectrum 2004;41(12): 44-9.

[3] Zamora I, San Martin JI, Mazón AJ, San Martín JJ, Aperribay V. Emergent technologies in electrical microgeneration. International Journal of Emerging Electric Power Systems 2005;3(2) Article 1092; Available at: 〈http://www. bepress.com/ijeeps/vol3/iss2/art1092 >.

[4] Upson S. How free is solar energy? IEEE Spectrum 200;45(2):72-72.

[5] Dalton GJ, Lockington DA, Baldock TE. Feasibility analysis of stand-alone renewable energy supply options for a large hotel. Renewable Energy 2008; 33(7):1475-90.

[6] Sauter R, Watson J. Strategies for the deployment of micro-generation: implications for social acceptance. Energy Policy 2007;35(5):2770-9.

[7] Allen SR, Hammond GP, McManus MC. Prospects for and barriers to domestic micro-generation: a United Kingdom perspective. Applied Energy 2008; 85(6):528-44.

[8] Watson J. Co-provision in sustainable energy systems: the case of microgeneration. Energy Policy 2004;32(17):1981-90.

[9] Manwell JF, McGowan JG, Rogers AL. Wind energy explained-theory, design and application. New York: Wiley; 2002.

[10] Givoni B. Climate considerations in building and urban design. New York: Wiley; 1998.

[11] Patel MR. Wind and solar power systems: design, analysis and operation. London: Taylor \& Francis; 2006.

[12] Twidell J, Weir T. Renewable energy resources. 2nd ed. London: Taylor \& Francis; 2006.

[13] TamizhMani G, Ji L, Tang Y, Petacci L. Photovoltaic module thermal/wind performance: long-term monitoring and model development for energy rating. In NCPV and solar program review meeting, Denver, 2003. p. 936-9.

[14] Jenkins DP, Fletcher J, Kane D. Model for evaluating impact of battery storage on microgeneration systems in dwellings. Energy Conversion and Management 2008;49(8):2413-24.

[15] Kelleher J. An economic assessment of the renewable micro-generation of electricity. BE report, Department of Electronic Engineering, NUI Maynooth, 2008.

[16] Fairley P. Solar cell squabble. IEEE Spectrum 2008;45(4):36-40.

[17] Stevenson R. First solar: quest for the $\$ 1$ watt. IEEE Spectrum 2008;45(8): 23-7.

[18] Staudt L, Ringwood JV. Control and sizing of flow battery electricity storage for wind turbines operating as autoproducers. In: European wind energy conference, Milan, May 2007.

[19] Binduhewa PJ, Renfrew AC, Barnes M. Ultracapacitor energy storage for MicroGrid micro-generation. In: 4th IET conference on power electronics, machines and drives (PEMD), April 2008, p. 27-274.

[20] Dali M, Belhadj J, Roboam X, Blaquiere JM. Control and energy management of a wind-photovoltaic hybrid system. In: European conference on power electronics and applications, September 2007, p. 1-10. 